FACULDADE DE CIÊNCIAS ECONô MICAS dA UFRGS
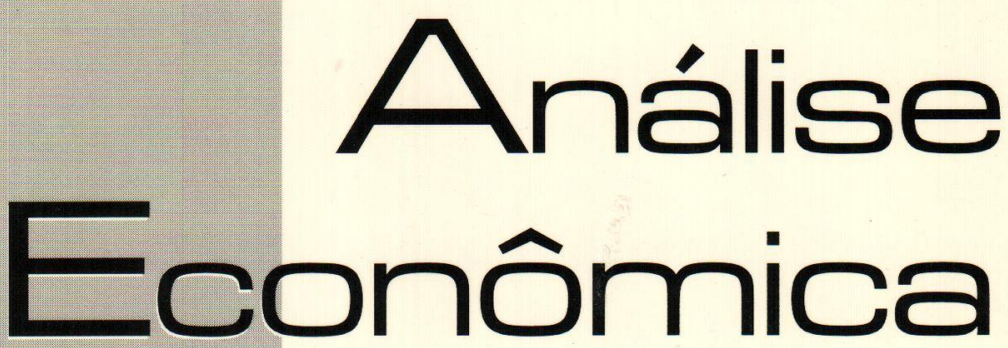

ESCOLHA DE PORTFÓLIO, INVESTIMENTO E NĀO. NEUTRALIDADE DA MOEDA

JOSÉ LUIS OREIRO

REFORMAS NA AROUITETURA FINANCEIRA INTERNACIONAL: NOVIDADES NO FRONT? ANDRÉ MOREIRA CUNHA

MERCOSUR'S CHANGE IN TRADE PATTERNS ANDRÉ FILIPE ZAGO DE AZEVEDO

O IMPACTO DA COMPOSICÃO SETORIAL, DOS FLUXOS INTRA-SETORIAIS E DA ABERTURA COMERCIAL NA PARTICIPAÇÁO DE MERCADO DAS EXPORTAÇÓES BRASILEIRAS

CLÉSIO LOURENÇO XAVIER E EMERSON FERNANDES MARÇAL

O EFEITO BALASSA-SAMUELSON E A PARIDADE DO PODER DE COMPRA NA ECONOMIA BRASILEIRA CLÁUDIO ROBERTO FÓFFANO VASCONCELOS

CICLOS Y FLUCTUACIONES FINANCIERAS: LA IRREGULAR DINÁMICA ECONÓMICA

SARY LEVY-CARCIENTE

O PENSAMENTO DE KARL POPPER: AS DIFERENTES INTERPRETACÓES DOS METODÓLOCOS DA CIENCIA ECONÓMICA

SOLANCE REGINA MARIN E RAMÓN GARCÍA FERNÁNDEZ

A EXPANSÃO DO ESCOPO TEMÁTICO DAS NEGOCIAÇÓES COLETIVAS DE TRABALHO CARLOS HENRIQUE HORN

EFEITOS DO CAPITAL SOCIAL E DO CAPITAL POLITICO NO DESENVOLVIMENTO ECONOMMICO SIMULAÇOES PARA PAISES E ESTADOS BRASILEIROS

RONALDO A. ARRAES, RICARDO CANDÉA S. BARRETO E VLADIMIR KÜHL TELES

O PROBLEMA DE RISCO MORAL NO MERCADO BRASILEIRO DE ASSISTÊNCIA MÉDICA SUPLEMENTAR LUCIANA PINTO DE ANDRADEE SABINO DA SILVA PÓRTO JÚNIOR

ANO

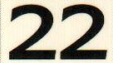

No 41

Março, 2004 
Universidade Federal do Rio Grande do Sul

Reitora: Profo. Wrana Maria Panizzi

Faculdade de Ciencias ECONOMICAS

Diretora: Prof Pedro César Dutra Fonseca

Centro de Estudos e Pesquisas Economicas

Diretor: Prof. Gentil Corazza

Departamento de Ciencias Económicas

Chefe: Prof. Ricardo Dathein

Curso de Pós-Graduação em Economia

Coordenador: Prof. Eduardo Pontual Ribeiro

Programa de Pó-Graduação em Desenvolvimento Rural

Coordenador: Prof. Jalcione Almeida

CONSElHo EDITORIAL:

Carlos G. A. Mielitz Netto (UFRGS), Eduardo A. Maldonado Filho (UFRGS), Eduardo P. Ribeiro (UFRGS), Eleutério F. S. Prado (USP), Eugênio Lagemann (UFRGS), Fernando Cardim de Carvalho (UFRJ), Fernando Ferrari Filho (UFRGS), Fernando de Holanda Barbosa (FGV/RJ), Flávio Vasconcellos Comim (UFRGS), Gentil Corazza (UFRGS), Giácomo Balbinotto Netto (UFRGS), Gustavo Franco (PUC/RJ), Jan A. Kregel (UNCTAD), João Rógério Sanson (UFSC), Joaquim Pinto de Andrade (UnB), Jorge Paulo Araújo (UFRGS), Juan H. Moldau (USP), Marcelo S. Portugal (UFRGS), Maria Alice Lahorgue (UFRGS), Paul Davidson (University of Tennessee), Paulo D. Waquil (UFRGS), Pedro C. D. Fonseca (UFRGS), Philip Arestis (Levy Economics Institut of Bard College), Roberto C. de Moraes (UFRGS), Ronald Otto Hillbrecht (UFRGS), Sabino da Silva Porto Jr. (UFRGS), Stefano Florissi (UFRGS) e Werner Baer (University of Illinois at Urbana-Champaign).

COMISSĀO EDITORIAL:

Eduardo Augusto Maldonado Filho, Fernando Ferrari Filho, Gentil Corazza, Marcelo Savino Portugal, Paulo Dabdab Waquil e Roberto Camps Moraes.

EDITOR: Prof. Fernando Ferrari Filho

Editor Adjunto: Prof. Gentil Corazza

SeCretária: Paulo Roberto Eckert

REVISÃO DE TEXTOS: Vanete Ricacheski

EdITORAÇÃo Eletrónca: Vanessa Hoffmann de Quadros

Fundador: Prof. Antônio Carlos Santos Rosa

Os materiais publicados na revista Análise Econômica são da exclusiva responsabilidade dos autores. É permitida a reprodução total ou parcial dos trabalhos, desde que seja citada a fonte. Aceita-se permuta com revistas congêneres. Aceitam-se, também, livros para divulgação, elaboração de resenhas e recensões. Toda correspondência, material para publicaçāo (vide normas na terceira capa), assinaturas e permutas devem ser dirigidos ao seguinte destinatário:

PROF. FERNANDO FERRARI FILHO Revista Análise Econômica - Av. João Pessoa, 52 CEP 90040-000 PORTO ALEGRE - RS, BRASIL Telefones: (051) 316-3513 - Fax: (051) 316-3990

Análise Econômica E-mail: rae@ufrgs.br

Ano 22, $n^{\circ} 41$, março, 2004 . Porto Alegre

Faculdade de Ciências Econômicas, UFRGS, 2004

Periodicidade semestral, março e setembro.

Tiragem: 500 exemplares

1. Teoria Econômica - Desenvolvimento Regional -

Economia Agrícola - Pesquisa Teórica e Aplicada -

Periódicos. I. Brasil

Faculdade de Ciências Econômicas,

Universidade Federal do Rio Grande do Sul. 


\title{
Mercosur's change in trade patterns
}

André Filipe Zago de Azevedo

\begin{abstract}
This paper examines the changes in Mercosur's trade patterns based on descriptive statistics, comparing the pre-integration period with the post-integration phase. The changes in imports and exports intra and extra-regionally at SITC three-digit level are analysed, in order to assess whether they are in tune with the bloc 'expected' comparative advantage. It also assesses the intra-bloc and extra-bloc trade intensities and propensities in quest of signs of either trade diversion or export diversion. The signs of export diversion are much more vivid than the traditional trade diversion, comprising approximately a third of the value exported to the rest of the world in the post-integration period.
\end{abstract}

Key Words: Regional Integration; Trade Policy; Mercosur.

Resumo: Este artigo examina as mudanças no padrão de comércio do Mercosul através de estatísticas descritivas, comparando o período préintegração com o período posterior a sua formação. As mudanças tanto nas importações com exportações intra e extra-bloco são analisadas ao nível de 3 dígitos da Classificação Padrão de Comércio Internacional para avaliar se elas estão em sintonia com as vantagens comparativas esperadas do bloco. O artigo também analisa os índices de intensidade $\mathrm{e}$ propensão de comércio intra e extra-bloco em busca de sinais de desvio de comércio ou desvio de exportação. A análise mostra que os sinais de desvio de exportação são muito mais claros do que aqueles relacionados ao desvio de comércio, compreendendo aproximadamente um terço do valor exportado para fora do bloco no período posterior à formação do Mercosul.

Palavras-Chave: Integração Regional; Política Comercial; Mercosul. JEL Classification: F13, F14, F15.

\footnotetext{
* This paper heavily relies on chapter 3 of my thesis submitted for the degree of $\mathrm{PhD}$ at University of Sussex. I would like to thank the Brazilian Federal Agency for Post-Graduate Education (CAPES) for the financial support. I'm also grateful to Nelly Berthault from UNCTAD for providing data and to Alan Winters, Peter Holmes, Edmund Fitzgerald and Jim Rollo for comments and suggestions.

1 Professor at the Universidade do Vale do Rio dos Sinos (UNISINOS). E-mail: azevedo@mercado.unisinos.br. Address: Av. Unisinos, 950, Centro 5, sala 5A 408, CEP 93022 000, São Leopoldo, RS
} 


\section{Introduction}

The analysis of Mercosur policies shows that despite not being a complete customs union yet, the regional agreement has promoted a reasonable deal of internal tariff liberalisation and advanced towards a common external policy. During the transition period (19911994), the intra-bloc tariffs were phased out, and by end 1994, most products originating within the bloc already circulated duty-free. In 1995, the common external tariff (CET) was introduced, and although many exemptions were allowed, the majority of products imported from third countries have a uniform import tariff in all members of the bloc. Besides regional integration, all bloc members were simultaneously involved in unilateral and multilateral trade liberalisation programmes and have undergone major macroeconomic changes in recent years with profound impacts on economic growth and exchange rates. All those factors are supposed to have affected the bloc trade pattern as well. Although attempts to assess the impact of a Preferential Trade Agreement (PTA) on trade patterns of member countries based on simple descriptive statistics have the common drawback of the inability to separate out the impact of the bloc from the other variables influencing the pattern of trade, they are useful insofar as they provide preliminary insights as a first step towards a more rigorous analysis.

This paper examines a set of trade performance indicators in search of evidence that Mercosur formation has affected trade flows both within the bloc and with the rest of the world. In the next section, the first set of descriptive statistics introduced are the share of intrabloc trade in total bloc trade, the intra-regional intensity of trade and the propensity to trade intra and extra-regionally, considering only total values of exports and imports. The third section looks for signs of trade diversion based on data disaggregated at the Standard International Trade Classification (SITC) three-digit level. It also deals with the issue of 'export diversion', in which non-member countries are prejudiced due to a reorientation of bloc exports towards the bloc at the expense of the rest of the world. Finally, the last section presents the conclusions. The analysis of all of the sets of indices includes Mercosur major trading partners ${ }^{2}$ covering the period from

${ }^{2}$ They are the EU (including all 15 members), NAFTA, ASEAN and the Andean Pact. Japan was considered together with ASEAN, generating the ASEAN+Japan bloc. 
1987 to 1998 , divided into three phases of four years each: $\left(1^{\text {st }}\right)$ the years that preceded the establishment of the bloc, from 1987 to 1990; $\left(2^{\text {nd }}\right)$ the transition period from 1991 to 1994 ; and $\left(3^{\text {rd }}\right)$ the years after introduction of the CET covering the period 1995-98.

\section{Trade Shares, Intensity and Propensity to Trade Indices}

The simplest indicator to assess the extent of regionalisation is the share of intra-regional trade in total trade, with a rise in intrabloc trade being taken as evidence of regionalisation. The structure of Mercosur trade is shown in table 1. The share of intra-bloc exports more than doubled from the period preceding integration when compared with the transition period, up from $8.0 \%$ to $16.2 \%$. This process continued in the following years when the share of intrabloc exports in total exports continued rising to reach $23.7 \%$. In the meantime, as result of the export growth bias towards the bloc, the share of Mercosur exports to third countries decreased from $92.0 \%$ in $1987-90$ to $76.3 \%$ in $1995-98$. This process provoked profound changes in the rank of the main destinations of the bloc exports. Mercosur became the main destination of its own exports in the postintegration period, surpassing the three previous major markets for Mercosur exports before the integration, NAFTA, the EU and ASEAN+Japan, respectively. The share of bloc exports to NAFTA, the major market for Mercosur exports in the pre-integration period, plunged from $24.4 \%$ in the four years previous to the bloc formation (when its share was more than three times larger than the intra-bloc share in bloc total exports) to $17.1 \%$ in $1995-98$. It transformed NAFTA into the third main destination of Mercosur exports, behind Mercosur and the EU, with the latter maintaining its share of Mercosur exports at around $22 \%$. Besides Mercosur, the only other bloc analysed with whom it was observed an increased in the share of Mercosur exports was the Andean Pact, from $3.8 \%$ in $1987-90$ to $4.7 \%$ in $1995-98$. 
Table 1: Value and Share of Mercosur Trade by Regional Blocs (US\$ million)

\begin{tabular}{|c|c|c|c|c|c|c|c|c|}
\hline FLOW & PERIOD & INTRA-BLOC & $\begin{array}{c}\text { TOTAL EXTRA: } \\
\text { BLOC }\end{array}$ & NAFTA & EU15 & $\begin{array}{l}\text { ASEAN + } \\
\text { JAPAN }\end{array}$ & $\begin{array}{c}\text { ANDEAN } \\
\text { PACT }\end{array}$ & WORLD \\
\hline \multirow{7}{*}{ Exports } & $1987-90$ & 3,460 & 39,641 & 10,535 & 9,522 & 3,505 & 1,626 & 42,999 \\
\hline & & $80 \%$ & $92.2 \%$ & $24.5 \%$ & $221 \%$ & $82 \%$ & $3.8 \%$ & $1000 \%$ \\
\hline & $1990-94$ & 8,638 & 44,570 & 11,015 & 13,966 & 4,367 & 2,350 & 53,168 \\
\hline & & $16.2 \%$ & $83.8 \%$ & $20.7 \%$ & $263 \%$ & $8.2 \%$ & $4.4 \%$ & $1000 \%$ \\
\hline & $1995-98$ & 18,480 & 59,402 & 13,283 & 16,943 & 5,520 & 3,629 & 77,530 \\
\hline & & $23.8 \%$ & $76.6 \%$ & $17.1 \%$ & $21.9 \%$ & $7.1 \%$ & $47 \%$ & $100.0 \%$ \\
\hline & Change/1 & $434.1 \%$ & $49.9 \%$ & $26.1 \%$ & $77.9 \%$ & $57.5 \%$ & $123.2 \%$ & $80.3 \%$ \\
\hline \multirow{7}{*}{ Imports } & $1987-90$ & 3,460 & 22,195 & 5,824 & 3,556 & 1,960 & 1,960 & 25,655 \\
\hline & & $13.5 \%$ & $86.5 \%$ & $22.7 \%$ & $13.9 \%$ & $7.6 \%$ & $3.1 \%$ & $100.0 \%$ \\
\hline & $1990-94$ & 8,638 & 37,667 & 11,536 & 10,843 & 3,155 & 1,117 & 46,306 \\
\hline & & $187 \%$ & $81.3 \%$ & $24.9 \%$ & $23.4 \%$ & $68 \%$ & $2.4 \%$ & $100.0 \%$ \\
\hline & $1995-98$ & 18,480 & 73,484 & 23,196 & 23,196 & 6,414 & 1,944 & 91,963 \\
\hline & & $20.1 \%$ & $79.9 \%$ & $25.2 \%$ & $25.7 \%$ & $7.0 \%$ & $2.1 \%$ & $100.0 \%$ \\
\hline & Change/ $/ 1$ & $434.1 \%$ & $231.1 \%$ & $298.3 \%$ & $564.4 \%$ & $227.3 \%$ & $143.7 \%$ & $258.5 \%$ \\
\hline
\end{tabular}

/1: Change in the value of trade from 1987-90 to 1995-98.

Source of the raw data: Comtrade - UNCTAD.

Although the shares of non-member countries had declined over the period analysed it is worth noting that it did not occur due to a reduction in the value of Mercosur exports to third countries, which increased by $49.9 \%$ from $1987-90$ to $1995-98$. This, in fact, just emphasises the significant reorientation of Mercosur exports towards the bloc, which augmented by $434.1 \%$ in the same period, almost ten times the rise observed in exports to non-member countries, up from US $\$ 3.5$ billion to US $\$ 18.5$ billion. The value of exports to NAFTA and the EU, the main pre-integration markets to the bloc, increased by $26.1 \%$ and $77.9 \%$, respectively, while they went up by $123.2 \%$ to the Andean Pact and by $57.5 \%$ to ASEAN+Japan.

The picture changes considerably if one looks at import performance in the same period. Again the growth rate of intra-bloc imports exceeded the rise in imports from outside the bloc but the difference was not so impressive as in the case of exports. While the value of intra-bloc imports increased by $434.1 \%$, imports from third countries went up $231.1 \%$, with the imports from the EU growing even more than intra-bloc imports, by an astonishing $564.4 \%$, followed by NAFTA with $298.3 \%$. Hence, the share of intra-bloc imports in total bloc imports increased from $13.5 \%$ in the four years preceding integration to $20.1 \%$ in $1995-98$. The EU and NAFTA also experienced an increment in their share of Mercosur total imports. 
The share of total imports of the bloc from NAFTA, for instance, rose from $22.7 \%$ to $25.2 \%$, while the share of total imports from the EU almost doubled from $13.9 \%$ to $25.7 \%$, becoming the bloc major supplier in place of NAFTA. All the remaining blocs registered a decline in their shares of Mercosur imports throughout the period. However, this was entirely due to the sharp increase in the value of imports from the own bloc, the EU and NAFTA, since the growth of Mercosur imports from these PTAs was also, by no means, negligible (227.3\% from ASEAN + Japan and 143.7\% from Andean Pact). Figure 1 reports the annual value of total Mercosur trade with both members and non-member countries and helps to illustrate how increasingly unbalanced Mercosur trade has become since 1994. The significant trade surpluses registered by members of the bloc with the rest of the world at the end of the 1980s begins to shrink rapidly by the beginning of nineties until disappears completely in 1994. From this year on the bloc starts to register increasing trade deficits that reach a peak in 1997 with US $\$ 18.7$ billion, declining slightly in 1998. Such contrasting performance of exports and imports suggests the existence of competitiveness problems in addition to the strong trade liberalisation.

Figure 1: Mercosur Intra and Extra-Bloc Trade (1987-98)

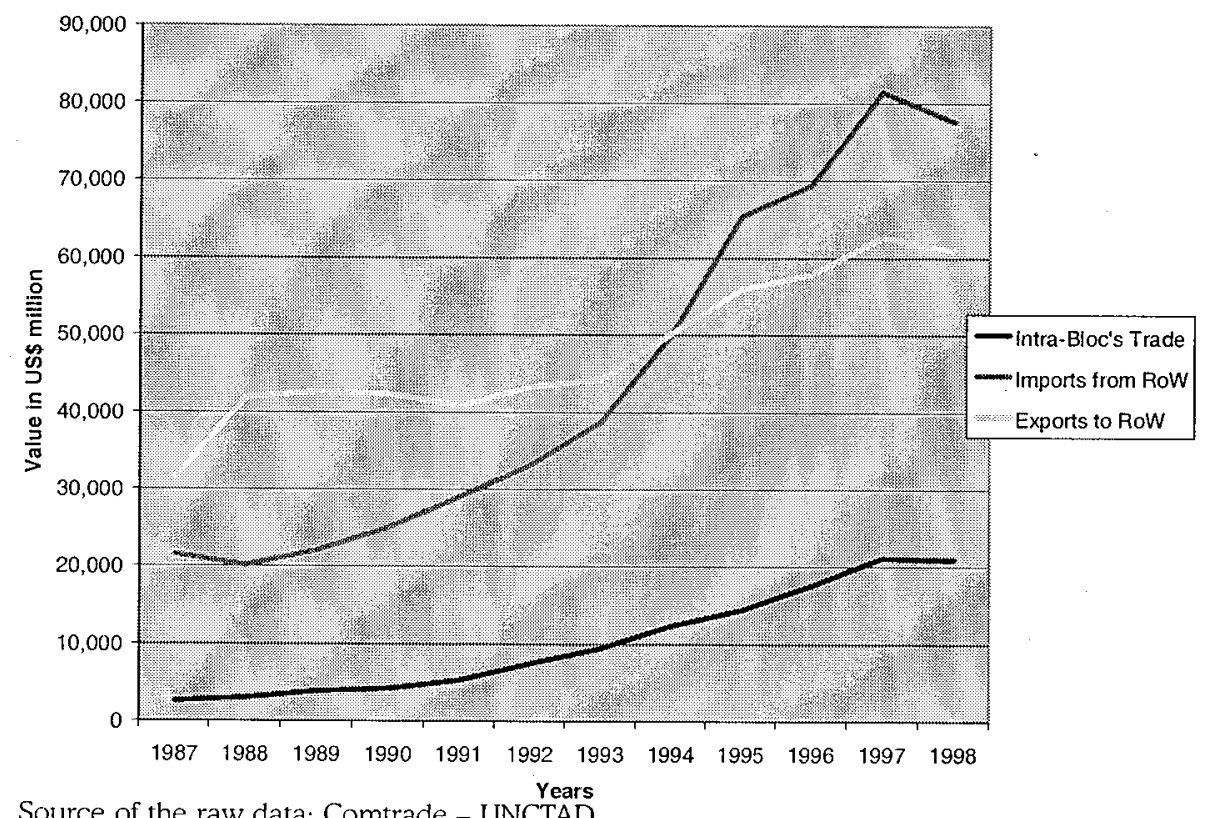

Source of the raw data: Comtrade - UNCTAD 
Although useful to shed light on the issue of the changing importance of different markets, trade share analysis can be misleading since a country trade pattern is influenced by many different factors such as the commodity composition of trade, the share of GDP traded and the relative transaction costs of trading with different countries. Anderson and Norheim (1993) point out that these factors, in turn, are related to history, geography and government policies of the country. In this sense there are a number of reasons besides the integration process that could be affecting trade shares, which are not depicted by just looking at trade shares. An attempt to address some of these issues has been made by adjusting regional trade shares using as a parameter the relevance of the region in world trade, obtained by the ratio of regional trade share to region share of the world trade, generating the Trade Intensity Index $\left(I_{i j}\right)$. This index has been extensively employed to measure the direction and level of international trade (e.g. Primo Braga et al., 1994; and Frankel, 1997) serving to point out the relative importance of changes in trade between countries, especially those with a small share in world trade, as is the case of Mercosur members. If trade is not geographically biased, which means the trade share among the countries exactly matches the share of the bloc in world trade, the ratio will be equal to 1 . If the index assumes a value above (below) unity, the countries have a greater (smaller) trade than could be expected based on the share of the importer in world trade. By definition, the index of intensity of region $\mathrm{i}$ exports with region $\mathrm{j}$ is:

$$
I i j={\frac{x_{i j}}{m_{j}}}^{3}
$$

Where:

$\mathrm{x}_{\mathrm{ij}}$ : the share of exports of region $\mathrm{i}$ to region $\mathrm{j}$;

$m_{j}$ : the share of region $j$ in world imports (net of imports of region $\left.i\right)^{4}$.

\footnotetext{
${ }_{3}$ While this formula applies for the export intensity index, replacing exports by imports in the numerator and imports by exports in the denominator will generate the import intensity index. ${ }^{4}$ As there should be intra-bloc trade in region $i$, Anderson and Norheim (1993) suggested two ad hoc adjustments to equation 1 in the case of intra-regional trade intensity index: (i) instead of subtracting all of region i imports from the world imports, it should be reduced by only one n-th of that amount in the denominator of $\mathrm{m}_{\mathrm{i}}$ (where $\mathrm{n}$ is the number of members of the region); (ii) also it should subtract one $n$-th of region $i$ imports from region $j$ imports in the numerator. In the case of the extra-regional trade intensity index, only the first of these adjustments is necessary. However, due to the small size of Mercosur, the difference between these results and the standard approach is negligible, so the original formulation was maintained.
} 
Table 2 shows Mercosur import and export intensity indices. Although the share of intra-bloc exports in total bloc exports rose substantially throughout the period analysed, its impact on the export intensity index was deadened by the increase in the share of Mercosur in world imports, up from $0.68 \%$ in $1987-1990$ to $1.27 \%$ in $1995-98$. Despite this, the index of intensity of intra-Mercosur exports increased significantly from 11.5 in the pre-integration period to 18.4 in the four years after the transition period. Meanwhile, the extra-bloc export intensity index declined steadily after the bloc formation from 0.93 to 0.78 , pushed down mostly by the poor performance of the bloc exports to NAFTA. However, this trend was not generalised, since for both the EU and the Andean Pact, the bloc export intensity index went up slightly during this period. Besides the changes in the export intensity index it is also noteworthy that it was substantially above unity for intra-bloc trade in 1987-90, denoting a regional bias of bloc exports even before the formal establishment of the bloc. This could stem from a number of factors, some of which are episodic, such as previous bilateral trade agreements between Argentina and Brazil in late-1980s and anticipation by the firms of the PTA formation leading to a reorientation of their exports towards the bloc, and some of which are structural, like distance, stage of development and common language and history 5 .

Table 2: Mercosur Trade Intensity Index by Regional Blocs

\begin{tabular}{|c|c|c|c|c|c|c|c|c|}
\hline FLOW & PERIOD & INTRA-BLOC & $\begin{array}{c}\text { TOTAL } \\
\text { EXTRA-BLOC }\end{array}$ & NAFTA & EU15 & $\begin{array}{l}\text { ASEAN + } \\
\text { IAPAN }\end{array}$ & $\begin{array}{c}\text { ANDEAN } \\
\text { PACT }\end{array}$ & WORLD \\
\hline & $1987-90$ & 11.54 & 0.93 & 1.27 & 0.53 & 0.80 & 5.61 & 100 \\
\hline \multirow[t]{3}{*}{ Exports } & $1990-94$ & 18.14 & 0.85 & 1.02 & 0.65 & 0.69 & 593 & 1.00 \\
\hline & $1995-98$ & 18.42 & 0.78 & 0.80 & 0.59 & 0.59 & 5.72 & 1.00 \\
\hline & Change/ & 6.88 & -0.15 & -0.47 & 0.06 & -0.21 & 0.11 & 0.00 \\
\hline \multirow[t]{4}{*}{ Imports } & 1987.90 & 11.56 & 0.88 & 1.43 & 0.34 & 0.64 & 3.19 & 100 \\
\hline & $1990-94$ & 17.82 & 0.82 & 1.45 & 0.58 & 0.47 & 3.05 & 1.00 \\
\hline & $1995-98$ & 18.45 & 081 & 1.42 & 0.65 & 0.50 & 2.65 & 1.00 \\
\hline & Change/l & 6.89 & -0.07 & -0.01 & 0.31 & -0.13 & .0 .54 & 0.00 \\
\hline
\end{tabular}

/1: Change in the value of trade from 1987-90 to 1995-98.

Source of the raw data: Comtrade - UNCTAD.

${ }^{5}$ See, for example, Eichengreen and Irvin (1997) and Frankel (1997) for more details about the causes of the so-called "anticipation effects" of trade blocs. 
The extra-bloc import intensity index, in turn, declined over the period analysed, although it remained stable for NAFTA and went up in the case of the EU due to the sharp increase in the share of imports coming from that region, declining in all remaining blocs. While the EU index almost doubled from 0.34 in the pre-Mercosur period to 0.65 in the post-integration period the intra-bloc index went up from 11.6 to 18.5 . In contrast to what occurred with intra-bloc exports intensity index, its import counterpart was boosted by the reduction in Mercosur share in world exports. The sharp increase in Mercosur import intensity index from the EU, besides the stabilisation of NAFTA index above unity (1.43), demonstrates that the increment in regional bias did not occur at the expense of the two major trading partners of the bloc before the integration. Moreover, the reduction of the bloc import intensity index in relation to ASEAN+Japan was much smaller than the export intensity index. In addition, the overall extra-bloc export intensity index declined more rapidly than its import counterpart denoting that the regional bias became more prominent on the export side.

Regional trade agreements are usually accompanied by changes in trade policy, which affect a country's trade-to-GDP ratio. This was the case of Mercosur, in which its members underwent a substantial trade liberalisation process along with formation of the bloc. In such cases, the establishment of a PTA could result in significant trade creation, so that, even though its extra-bloc trade intensity index falls, trade with non-member countries, expressed as proportion of GDP, increases as the economy becomes more open overall. In order to capture the combined effect of these two changes, in openness and in extra-regional trade intensity, the propensity to trade intra and extraregionally $\left(P_{i j}\right)$ was developed. The propensity to export index assumes the following form:

$$
P i j=\frac{t_{i j}}{m_{j}}
$$

Where:

$t_{i j}$ : exports of region $i$ to region $j$ divided by i's GDP;

$m_{j}$ : the share of region $j$ in world imports (net of imports region $\left.i\right)^{6}$.

${ }^{6}$ Changing exports to imports in both the numerator and denominator will generate the propensity to import index. 
This index is useful for across-time comparisons of trade between a PTA and its non-member partners when the trade-to-GDP ratio has changed at the same time as the policy changes that affected the intensity to trade index. However, as Anderson and Norheim (1993) point out, this index should not be used for comparing across countries or regions with different sizes at a point in time. The propensity to trade index is dependent on the size of economy, and there is plenty of evidence of the negative relationship between the size of the economies and their trade-to-GDP ratios?

Table 3 gives the value of the propensity to export and import both intra and extra-regionally. The value of the intra-bloc propensity to export index increased from 0.97 in the pre-integration period to 1.29 in the post-integration period while its import counterpart rose even further from 0.58 to 1.53 in the same period. Here again it is possible to identify different performances of intra and extra-regional indices. The propensity to export to all other blocs but the EU, which remained stable, declined from 1987-90 to 1995-98 provoking a reduction of the propensity to export extra-regionally from 0.08 to 0.05 . In contrast, the propensity to import extra-regionally showed an increase over the period analysed, which was spread all over the blocs, although the intra-regional index presented the most significant increment. These opposite trends in the export and import propensity indices reflect the fact that Mercosur import growth from all blocs was higher than the bloc GDP growth, while the rise in value of exports to most blocs was not able to catch up with changes in the bloc GDP.

Table 3: Mercosur Propensity to Trade by Regional Blocs

\begin{tabular}{|c|c|c|c|c|c|c|c|c|}
\hline PERIOD & FLOW & INTRA-BLOC & $\begin{array}{l}\text { TOTAL EXTRA. } \\
\text { BLOC }\end{array}$ & NAFTA & EUI5 & $\underset{\text { JAPAN }}{\text { ASEAN }+}$ & $\begin{array}{l}\text { ANDEAN } \\
\text { PACT }\end{array}$ & WORLD \\
\hline & 1987.90 & 0.97 & 0.08 & 0.11 & 004 & 0.07 & 0.47 & 0.08 \\
\hline \multirow[t]{3}{*}{ Exports } & $1990-94$ & 1.38 & 0.06 & 008 & 0.05 & 0.05 & 0.45 & 008 \\
\hline & $1995-98$ & 1.29 & 0.05 & 0.06 & 004 & 0.04 & 0.40 & 0.07 \\
\hline & Change & 033 & -0.02 & .0 .05 & 0.00 & .0 .03 & .007 & -0.01 \\
\hline \multirow{4}{*}{ Imports } & 1987.90 & 0.58 & 0.04 & 007 & 0.02 & 0.03 & 0.16 & 0.05 \\
\hline & $1990-94$ & 118 & 0.05 & 0.10 & 004 & 0.03 & 0.20 & 0.07 \\
\hline & $1995-98$ & 153 & 007 & 0.12 & 005 & 004 & 0.22 & 008 \\
\hline & Change & 0.96 & 0.02 & 0.05 & 0.04 & 0.01 & 0.06 & 0.03 \\
\hline
\end{tabular}

Source of the raw data: Comtrade - UNCTAD.

${ }^{7}$ See, for instance, Perkins and Syrquin (1989) for a survey of empirical evidence of this relationship. 
The foregoing analysis, showing a significant difference in performance between exports and imports of Mercosur, suggest that other factors, such as exchange rates and economic growth, may well have influenced its trade pattern in addition to general and regional trade liberalisation. The appreciation of Argentinean and Brazilian currencies after implementation of their stabilisation plans in 1991 and 1994, respectively, caused a significant loss in competitiveness. Moreover, the economic recovery observed in these two countries in early 1990s, after years of poor economic growth, also seems to have contributed to boost imports and constrain exports during this period. Thus, although this initial analysis based on trade shares, intensity and propensity to trade indices does not allow to isolate the 'bloc effect' from the other factors influencing the bloc trade patterns, it permits to identify some clear trends during the period analysed such as:

- A clear dissociation between the growth rate of the value of bloc exports to non-member countries vis-à-vis both intra-bloc trade and imports from third countries, with the former falling sharply behind the latter two. Although the level of exports to the rest of the world did not fall, its increase was only a fraction of that observed in imports from both members and non-member countries.

- Even after controlling for geographical bias and trade policies, the different pattern of intra and extra-bloc exports remained a distinctive feature of Mercosur integration process. While the bloc propensity to import increased for all regions analysed in this chapter, the opposite occurred with the extra-bloc propensity to export.

\section{In Quest of Signs of Trade Diversion}

The previous section indicated that there was a significant expansion in trade, both in absolute terms and as a share of total trade, among Mercosur members after the bloc formation. It also showed that, despite the increased trade with the rest of the world, the rate of growth of imports dramatically exceeded that of exports. However, from this data it is not possible to infer to what extent the increase in intra-bloc trade reflects Viner's (1950) trade creation or trade diversion. There are a number of approaches that provide preliminary insights into this issue. Initially this section looks at the value of imports from the rest of the world, at SITC 03-digit level, 
before and after the bloc formation in search of cases in which there was a fall in absolute imports from non-member countries. In this context, a decline in import volumes from non-member countries associated with an increase in imports from bloc members would suggest trade diversion ${ }^{8}$. However, as suggested by Krueger (1999: 12), "in a dynamic setting such as the growing world economy one could expect changes in demand and supply to affect not the absolute values of trade but the trade shares in total trade'? Hence, the second approach looks at changes in shares of both intra and extra-bloc imports in total Mercosur imports. In this context, if the share of intrabloc imports increases in products in which there is a presumption that the bloc has a comparative advantage it will be in tune with the expected pattern. However, if the shift in shares towards the bloc occurs in sectors where the bloc is not expected to enjoy a comparative advantage there is scope for fears of trade diversion. The comparative advantage is proxied by two indicators based on bloc exports. The first is Balassa's (1965) revealed comparative advantage (RCA) index, which depends on the ratio of the share of a product in a country exports to the share of that product in world exports. The second compares the performance of Mercosur exports to members and non-member countries.

Besides analysing the prospects of trade diversion based on the performance of Mercosur imports, this section also examines the likelihood of so-called 'export diversion' ${ }^{10}$. Recently some authors have challenged the usual analysis of regional blocs, which assess the welfare and the trade creation-trade diversion issue on members and non-member countries based on bloc imports. Suggesting that the conventional wisdom suffers from a mercantilist bias, Winters (1997) stresses that the bloc exports are, in fact, a better measure of the effects of a regional bloc on welfare of the rest of the world, since

\footnotetext{
${ }^{8}$ There are a number of potential shortcomings with this approach. The first, and more obvious, is that the supply of exports from non-members to the bloc could be affected by other factors not correlated with the bloc formation.

${ }^{9}$ As stressed by Krueger (1999: 12), 'there is nothing in theory that says that shares should remain constant. One country might have low average costs and rapidly rising marginal costs, while another might have a higher average cost, but a flat (and therefore after a point lower than the first country's) marginal cost curve.'

${ }_{10}$ This term was coined by Soloaga and Winters (2001) to express a decline in the expected level of exports of a PTA to non-member countries, as a result of bloc formation, with the expected level being defined by a gravity model.
} 
welfare is related to consumption and in this case it is determined by what non-member countries import rather than what they export. The author demonstrates, in a very straightforward approach, how changes along and in the slope of non-member countries offer curve can change their welfare, stressing that the two relevant indicators to be considered, as far as welfare of non-member countries is concerned, are non-member countries terms of trade and members exports.

Yeats (1997), in turn, proposed a new methodology to look at the trade diversion issue based on the PTAs' exports. The author argues that approaches to considering the effects of PTAs based on changes in import shares are not able to deal with issues of efficiency in production. Assuming that intra-bloc imports should match intrabloc exports and that member exports compete with the same third country exports within and outside the bloc, Yeats infers that a greater dynamism of exports to bloc members compared with third countries should be caused by the bloc preferences. He uses the regional orientation and the revealed comparative advantage indices to measure the most dynamic products in intra-bloc trade and whether the bloc trade pattern has evolved in line with efficiency criteria, respectively ${ }^{11}$. In light of that, two additional exercises are undertaken to infer whether Mercosur formation was likely to provoke negative effects on non-member countries welfare, based on bloc exports to the rest of the world. First, absolute changes in imports are replicated to analyse the changes in the value of intra and extra-bloc exports in the incomplete customs union period in relation to the pre-integration phase. The presence of 'export diversion' would be likely whenever Mercosur exports to outside the bloc declined at the expense of increasing intra-bloc trade. Second, a slightly modified version of Yeats approach, based on the regional orientation index, is presented. Besides looking at the commodity groups that showed the highest growth in regional orientation, this section also analyses the evolution of intra and extra-bloc exports of the bloc major export products, in

\footnotetext{
$"$ His approach has been widely criticised on many grounds (e.g. Devlin, 1997; and Nagarajan, 1998). The major criticism lies in his failure to address the developments on the import side. Since the traditional customs union theory relies on the impact of a PTA on its imports from within and outside the bloc, his approach has been viewed as a heresy. It has also come under attack on the basis that the demand for bloc exports should also be taken into account, in special the structure of protection and the pattern of demand in non-member countries.
} 
order to evaluate whether eventual changes in its composition are in tune with comparative advantage.

In summary, this section uses both an 'import only' approach in search of signs of trade diversion, and an 'export only' approach to deal with the issue of 'export diversion'. Trade diversion will occur in the 'import only' model whenever a commodity group:

- Shows an absolute decline in imports from the rest of the world while increasing within the bloc (absolute changes) or;

- Presents an expansion in its share of intra-bloc trade at expense of imports from non-member countries and;

- Has not comparative advantage, with comparative advantage being proxied by the revealed comparative advantage index and the performance of the commodity group exports to the rest of the world (share changes).

Meanwhile 'export diversion' is a likely feature of the bloc whenever a sector:

- Shows an absolute decline in exports to the rest of the world while increasing within the bloc (absolute changes) or;

- Presents a decline in the share of its exports in the rest of the world markets while increasing within the bloc (share changes).

\section{1 'Imports only' Analysis}

The analysis of Mercosur import data at SITC three-digit level shows that in only a small fraction of commodity groups are signs of trade diversion, with the value of imports from third countries declining while rising within the bloc comparing the post-integration (1995-98) with the pre-integration period (1987-90), as shown in table 4. This occurred in less than 10 percent of the commodities (21 out of 238 commodities) at that aggregation level, or $8 \%$ of the total intrabloc trade, over the period 1995-98. The only product in which there was a significant reorientation of imports towards the bloc in detriment to the rest of the world was crude petroleum (333), with imports from non-member countries plunging by about US $\$ 1,925$ million. Even in this case the reduction in imports from outside the bloc exceeded by far the expansion of imports within the bloc, indicating the increase in domestic production that took place during the early 1990s, especially in Brazil. All remaining products showed an absolute decline in imports from the rest of the world not 
surpassing US $\$ 50$ million, making the overall fall in all these 21 sectors reach US $\$ 2,135$ million. However, in some cases, such as fresh meat (011) and wheat (046), the rise in imports from Mercosur members significantly exceeded the reduction in imports from non-member countries, denoting a much greater potential loss for the latter assuming the formation of the bloc was responsible for these trade pattern changes. However, based on the whole picture, one cannot conclude that the bloc diverted trade in most cases at this level of aggregation. Nevertheless, it is hard to believe that the significant rise in imports from non-member countries could be attributed exclusively to the establishment of the bloc ${ }^{12}$. However, it could only be properly inferred using an approach that permit to separate out these different effects.

Table 4: Products in which the Value of Extra-Bloc Imports Decreased and Intra-Bloc Imports Increased (US\$ 1,000)

\begin{tabular}{cccccc}
\hline SITC & DESCRIPTION & \multicolumn{2}{c}{ EXIRA-BLOC IMPORTS } & \multicolumn{1}{c}{ INTRA-BLOC IMPORTS } \\
\hline & & POS-MERC/ & CHANGE/2 & POS-MERC/ CHANGE/2 \\
333 & CRUDE PETROLEUM & $2,509,802$ & $-1,924,946$ & 827,254 & 827,245 \\
011 & MEAT RRESH, CHILLD, ROZEN & 49,117 & $-41,500$ & 329,288 & 195,356 \\
718 & OTH POWER GENERATG MACHY & 88,843 & $-34,876$ & 17,500 & 14,866 \\
282 & IRON AND SIEEL SCRAP & 665 & $-25,331$ & 1,256 & 681 \\
611 & LEATHER & 62,740 & $-19,440$ & 145,902 & 11,339 \\
672 & IRON, STEEL PRIMARY FORMS & 88,865 & $-16,660$ & 108,338 & 43,188 \\
288 & NONERR METAL SCRAP NES & 16,845 & $-15,893$ & 6,477 & 2,394 \\
046 & WHEAT ETC MEAL OR RLOUR & 923 & $-13,279$ & 75,729 & 75,666 \\
287 & BASE METAL ORES, CONC NES & 463,063 & $-11,038$ & 61,803 & 45,799 \\
001 & LIVE ANIMALS FOR FOOD & 33,757 & $-6,999$ & 103,191 & 89,065 \\
281 & IRON ORE, C NCENTRATES & 2,474 & $-6,522$ & 171,167 & 61,488 \\
686 & ZINC & 21,142 & $-5,796$ & 11,898 & 11,021 \\
071 & COFEE AND SUUSTITUTES & 16,946 & $-4,249$ & 105,440 & 67,778 \\
212 & FURSKINS, RAW & 1,844 & $-2,419$ & 447 & 375 \\
289 & PREC MT L ORES, WASTE NES & 240 & $-2,062$ & 94 & 94 \\
971 & GOLD, NON MONETARY NES & 420 & $-1,874$ & 13 & 13 \\
667 & PEARL, PREC., SEMI-P STONE & 1,343 & $-1,223$ & 119 & 63 \\
277 & NATURAL ABRASIVES NES & 8,086 & -699 & 301 & 4 \\
613 & RUR SKINS TANNED, DRESSED & 254 & -387 & 3,597 & 2,148 \\
044 & MAIZF UNMILLED & 32,091 & -281 & 152,400 & 123,102 \\
883 & DEVELOPED CINEMA FLM & 394 & -30 & 103 & 84 \\
\hline
\end{tabular}

Source of the raw data: Comtrade - UNCTAD.

/1: it refers to the period 1995-98.

/2: change from 1987-90 to 1995-98.

${ }^{12}$ It is important to bear in mind that Mercosur members were involved in both unilateral and multilateral trade liberalisation along with regional liberalisation. 
As mentioned above, one should bear in mind that the value of imports is also affected by a myriad of different factors not related to the PTA formation itself. As a result, even those sectors that registered a rise in absolute imports from the rest of the world could be diverting trade away from more efficient producers outside the bloc. Indeed, looking at the overall picture, in exactly half of 238 SITC commodity groups the growth rate of intra-bloc imports exceeded the pace of imports from outside the bloc. However, it does not seem very plausible to admit that Mercosur members had the competitiveness edge over all the rest of the world in such large number of sectors. Thus, in what follows the issue of trade diversion will be examined based on changes in import shares rather than changes in absolute imports. In this approach, a rise in the share of intra-bloc trade in commodity groups in which Mercosur does not seem to enjoy a comparative advantage would suggest the presence of trade diversion. Two joint criteria were chosen to determine whether a product has comparative advantage. The first is a slightly modified version of Balassa's (1965) Revealed Comparative Advantage index (RCA), which excludes intra-bloc trade from both numerator and denominator, assuming the following form ${ }^{13}$ :

$$
R C A_{j}=\frac{X_{B j} / X_{B T}}{X_{W_{j}} / X_{W T}}
$$

Where:

$X_{B j}$ : value of bloc exports of product $j$ to third countries;

$\mathrm{X}_{\mathrm{BT}}$ : total value of bloc exports to non-member countries;

$\mathrm{X}_{\mathrm{wj}}$ : world exports of product $\mathrm{j}$ exclusive of intra-bloc trade;

$X_{\mathrm{wT}}$ : total world exports exclusive of intra-bloc trade.

The second criterion is the performance of the exports of the bloc in third markets. The argument is that if the bloc were able to increase the share of its exports of a specific product in both regional and extra-regional markets, it would imply that the product improved its overall competitive position. However, if the share of the bloc exports of this product in third markets fell while it increased within the bloc, it would indicate a possible source of trade diversion. Table 5 shows those SITC 03-digit commodity groups that showed an

\footnotetext{
${ }^{13}$ This follows Yeats (1997) argument that the RCA index should measure a country (or region) 'true abilities' to export in markets where it does not benefit from trade preferences.
} 
increase in the share of intra-bloc trade in total bloc imports that met these two criteria ${ }^{14}$. Under these criteria, the number of commodity groups that shows signs of trade diversion increases to 33 , representing $14 \%$ of total number of sectors (about $20 \%$ of total intrabloc trade in the post integration period) ${ }^{15}$. Seven of them gained more than 10 percentage points of share in intra-bloc trade in that period. In most cases the MFN import tariff applied on these products was above the average of $14.6 \%$ in 1998 , showing that those sectors benefited from a higher level of protection. In other cases, even when MFN tariffs were below the average, they went up significantly from 1994 to 1998 , as occurred in the case of zinc, in which the tariff almost doubled granting an increased preference level at intra-bloc trade.

This section shows that, although total imports went up sharply from both members and non-member countries, when one looks at a more disaggregated level it is possible to identify a number of cases in which the evolution of imports did not seem to be in tune with the bloc comparative advantage. It also suggests that those products with a higher increase in intra-bloc trade between the pre-integration period and the incomplete customs union were benefited by bloc preferences. However, those cases represent only a tenth or a seventh of the total sectors, depending on the method employed to analyse it, the absolute change and the change in the share of imports, respectively.

14 The table includes all commodity groups that showed an increase in the share of intra-bloc imports in total imports greater than $5 \%$, in order to eliminate spurious variations.

15 Besides those 33 commodity groups, 16 other gained more than 20 percentage points of share, 14 gained between 10 and 20 percentage points, and 36 gained between 10 and one point of share. On the other hand, 39 sectors either stayed the same or varied less than one percentage point, 48 lost between one and 10 percentage points in share, 26 lost between 10 and 20 points in share and 24 lost more than 20 percentage points. 
Table 5: Products with the Highest Increase in Share of Intra-Bloc Imports

\begin{tabular}{|c|c|c|c|c|c|c|}
\hline SITC & SITC REV 02 DESCRIPTION & $\begin{array}{l}\text { CHANGE IN } \\
\text { INTRA-BLOC } \\
\text { IMPORTS } \pi\end{array}$ & $\begin{array}{l}\text { RCA INDEX IN } \\
\text { POST-MERC }\end{array}$ & $\begin{array}{l}\text { CHANGE IN } \\
\text { EXTRA-BLOC } \\
\text { EXPORTS } \Pi\end{array}$ & $\begin{array}{c}\text { MPN IMPORT } \\
\text { TARIFF IN } \\
1994 / 2 \\
\end{array}$ & $\begin{array}{c}\text { MNN IMPORT } \\
\text { TARIF IN } \\
1998 / 2 \\
\end{array}$ \\
\hline 686 & ZINC & $32.9 \%$ & 0.71 & $0.21 \%$ & 6.56 & 12.13 \\
\hline 022 & MILK AND CREAM & $32.7 \%$ & 0.21 & $-0.15 \%$ & 16.14 & 18.33 \\
\hline 951 & WAR FIREARMS, AMMUNITION & $26.9 \%$ & 0.10 & $-0.04 \%$ & 15.50 & 2100 \\
\hline 782 & LORRIES, SPCL MTR VEHNES & $242 \%$ & 0.62 & $-108 \%$ & 18.65 & 24.15 \\
\hline 657 & SPECIAL TXTL FABRC, PRODS & $13.9 \%$ & 0.57 & $-0.14 \%$ & 14.56 & 19.47 \\
\hline 786 & TRAILERS, NONMOTR VEH, NES & $11.8 \%$ & 0.13 & $-0.01 \%$ & 12.81 & 18.50 \\
\hline 873 & METERS AND COUNTERS NES & $11.4 \%$ & 0.93 & $-0.08 \%$ & 17.67 & 19.87 \\
\hline 694 & STL, COPPR NAILS, NUTS, ETC & $84 \%$ & 021 & $-0.08 \%$ & 13.58 & 18.92 \\
\hline 682 & COPPER EXC CEMENT COPPER & $8.2 \%$ & 0.34 & $-0.20 \%$ & 863 & 13.31 \\
\hline 846 & UNDER GARMENTS KNITTED & $7.0 \%$ & 0.18 & $0.49 \%$ & 20.00 & 23.50 \\
\hline 677 & IRN, STL WIRE EXCL W ROD) & $6.6 \%$ & 0.40 & $-0.35 \%$ & 11.09 & 15.53 \\
\hline 725 & PAPER ETC MILL MACHINERY & $64 \%$ & 067 & $-106 \%$ & 12.11 & 16.66 \\
\hline 654 & OTH WOVEN TEXTILE FABRIC & $6.2 \%$ & 0.51 & $-0.22 \%$ & 1503 & 20.25 \\
\hline 64$]$ & PAPER AND PAPERBOARD & $6.1 \%$ & 0.95 & $-0.25 \%$ & 12.66 & 17.71 \\
\hline 667 & PEARL, PREC, SEMI-P STONE & $6.0 \%$ & 0.24 & $-0.14 \%$ & 875 & 12.33 \\
\hline 628 & RUBBER ARTICLES NES & $5.5 \%$ & 0.48 & $-0.09 \%$ & 14.48 & 17.65 \\
\hline 699 & BASE METAL MFRS NES & $51 \%$ & 0.27 & $.007 \%$ & 12.33 & 15.55 \\
\hline 791 & RAILWAY VEHCLES & $5.0 \%$ & 0.27 & $-0.68 \%$ & 12.93 & 17.78 \\
\hline 652 & COITON FABRICS, WOVEN & $4.8 \%$ & 0.67 & $-0.47 \%$ & 15.17 & 21.00 \\
\hline 621 & MATERIALS OF RUBBER & $4.1 \%$ & 0.36 & $-0.03 \%$ & 12.29 & 17.11 \\
\hline 778 & ELECTRICAL MACHINERY NES & $4.1 \%$ & 0.24 & $-0.12 \%$ & 15.30 & 17.51 \\
\hline 598 & MISCEL CHEM PRODUKTS NES & $38 \%$ & 0.32 & $-0.28 \%$ & 9.40 & 14.57 \\
\hline 111 & NON-ALCOHL BEVERAGES NES & $3.8 \%$ & 008 & $-0.01 \%$ & 1234 & 23.00 \\
\hline 772 & SWITCHGEAR ETC, PARTS NES & $3.4 \%$ & 0.18 & $-0.05 \%$ & 16.86 & 17.98 \\
\hline 773 & ELECTR DISIRIBUTNG EQUIP & $2.6 \%$ & 0.17 & $-0.53 \%$ & 17.00 & 19.57 \\
\hline 054 & VEG ETC FRSH, SMPLY PRSVD & $26 \%$ & 0.55 & $-0.04 \%$ & 6.74 & 11.59 \\
\hline 048 & CEREAL ETC PREPARATIONS & $2.5 \%$ & 0.19 & $-0.01 \%$ & 11.22 & 17.67 \\
\hline 516 & OTHER ORGANIC CHEMICALS & $2.5 \%$ & 0.67 & $-0.14 \%$ & 6.46 & 9.74 \\
\hline 223 & SEEDS FOR OTH FIXED OLIS & $1.9 \%$ & 0.23 & $-4.63 \%$ & 534 & 7.36 \\
\hline ו1ו & STEAM BOILERS \& AUX PLNT & $1.9 \%$ & 0.29 & $-0.03 \%$ & 12.44 & 17.75 \\
\hline 642 & PAPER, ETC, PRECUT, ARTS OF & $17 \%$ & 0.18 & $-0.35 \%$ & 1365 & 18.65 \\
\hline 874 & MEASURNG, CONTROLNG INSTR & $13 \%$ & 0.13 & $-0.01 \%$ & 13.07 & 15.81 \\
\hline 582 & PROD OF CONDENSATION ETC & $1.0 \%$ & 0.21 & $-0.05 \%$ & 11.55 & 15.11 \\
\hline
\end{tabular}

/1: change from 1987-90 to 1995-98.

/2: it reflects the average MFN tariff of Argentina and Brazil

Source of the raw data: Comtrade - UNCTAD

\section{2 'Export Diversion'}

As mentioned earlier, some authors argue that exports rather than imports of the bloc to the rest of the world are a better indicator of the effects of the bloc in non-member countries welfare. As Soloaga and Winters (2001: 8) point out "welfare is related to what you consume and that, ceteris paribus, is determined by what you receive 
from others rather than what you send to them". In this context, if formation of a PTA diverts exports to bloc members, instead of being sent to the rest of the world, the welfare of the latter is likely to be harmed. This section examines the performance of Mercosur exports to both members and non-member countries, relying on Yeats method to search for commodity groups that showed an increase in the share of intra-bloc exports in detriment to extra-bloc exports, and that are likely to have caused 'export diversion' according to the three following criteria. First, like the import analysis, the data was examined to determine whether there were sectors in which the level of exports to the rest of the world fell as intra-bloc exports increased. Second, the share of the bloc exports in third country markets decreased in the post-integration period. Finally, the performance of intra and extrabloc top ten export sectors of Mercosur is analysed, bearing in mind the changes in comparative advantage experienced by these sectors.

The analysis of changes in absolute values of exports to third countries shows that in 53 sectors, at SITC three-digit level; there was a decline in value of exports to the rest of the world accompanied by a rise in intra-bloc exports (table 6 shows only the first twenty sectors with the highest decline in absolute exports to non-member countries). This means that one quarter of categories presented signs of 'export diversion', according to the first criterion. The value of exports diverted in all these sectors reached US $\$ 2,952$ million. In contrast with imports, where most of the fall was concentrated in a single sector, the decline in value of exports to outside the bloc was more evenly distributed, with nine sectors presenting a reduction larger than US\$100 million.

Table 7 reports all commodity groups that met the second criterion described above. It is noteworthy that commodity groups with a quite high comparative advantage, with the RCA index exceeding 5, such as fruit (058) and meat (014), were unable to maintain their share in third country markets in 1995-98 vis-à-vis the pre-integration period. On the contrary, their shares in the rest of the world markets declined sharply by 6.0 and 5.4 percentage points, respectively. However, while falling behind the performance of their main competitors in third markets, they were capable of increasing their shares within the bloc by a few percentage points. It is also worth noting that four of these commodity groups belong to the top five export sectors of the bloc to the rest of the world, including feeding 
stuff for animals (081), which is the top export product to outside the bloc, with exports reaching US\$ 4,450 million in 1995-98. Overall, these commodities groups represented a third of total exports of Mercosur to outside the bloc in the post-integration period, showing a huge potential for export diversion. This poor performance of such important export products of the bloc in third markets help to explain the lack of dynamism of the bloc exports at the aggregate level.

Table 6: Products in which the Value of Extra-Bloc Exports Decreased and Intra-Bloc Exports Increased (US\$ 1,000)

\begin{tabular}{cccccc}
\hline SITC & DESCRIPTION & \multicolumn{2}{c}{ EXTRA-BLOC EXPORTS } & \multicolumn{2}{c}{ INTRA-BLOC EXPORTS } \\
\hline & & POS-MERC & CHANGE & POS-MERC & CHANGE \\
334 & PETROLEUM PRODUCTS, REFIN & 530,922 & $-485,513$ & 506,723 & 386,259 \\
072 & COCOA & 96,953 & $-328,479$ & 51,097 & 33,842 \\
268 & WOOL IEXC TOPSI, ANML HAIR & 139,089 & $-312,128$ & 23,186 & 14,984 \\
673 & IRON, STEEL SHAPES ETC & 305,724 & $-269,955$ & 75,428 & 64,459 \\
782 & LORRIES, SPCL MTR VEH NES & 369,633 & $-250,854$ & 944,261 & 926,395 \\
687 & TIN & 49,932 & $-155,384$ & 7,012 & 3,226 \\
781 & PASS MOTOR VEH EXC BUSES & 547,510 & $-152,383$ & $1,533,574$ & $1,466,106$ \\
583 & POLYMERIZATION ETC PRODS & 338,801 & $-122,834$ & 399,174 & 297,296 \\
674 & IRN, STL UNIV, PLATE, SHEET & 882,878 & $-109,586$ & 190,395 & 124,567 \\
424 & FIXED VEG OIL NONSOFT & 54,305 & $-83,700$ & 10,227 & 5,656 \\
843 & WOMENS OUTERWEAR NONKNIT & 45,339 & $-68,912$ & 47,298 & 40,917 \\
722 & TRACTORS NON-ROAD & 61,336 & $-59,597$ & 83,859 & 63,505 \\
894 & TOYS, SPORTNG GOODS, ETC & 76,600 & $-49,038$ & 28,613 & 23,002 \\
263 & COTTON & 276,430 & $-43,817$ & 316,557 & 180,194 \\
273 & STONE, SAND AND GRAVEL & 6,876 & $-42,868$ & 6,959 & 4,548 \\
752 & AUTOMTIC DATA PROC EQUIP & 149,418 & $-38,232$ & 65,968 & 48,890 \\
842 & MENS OUTERWEAR NOT KNIT & 26,791 & $-36,840$ & 40,716 & 32,852 \\
511 & HYDROCARBONS NES, DERIVS & 259,006 & $-35,953$ & 77,533 & 19,302 \\
725 & PAPER ETC MILL MACHNERY & 63,503 & $-34,126$ & 18,583 & 16,460 \\
845 & OUTERWEAR KNIT NONELASTC & 40,427 & $-32,214$ & 34,465 & 28,909 \\
\hline
\end{tabular}

Source of the raw data: Comtrade - UNCTAD. 
Table 7: Products in which the Share of Mercosur Exports in ROW Decreased

\begin{tabular}{|c|c|c|c|c|c|}
\hline SITC & SITC REV. 02 & $\begin{array}{c}\text { CHANGE IN SHARE } \\
\text { IN EXTRABLLO } \\
\text { MARKETS } \\
\end{array}$ & $\begin{array}{l}\text { CHANGE IN } \\
\text { SHARE IN INTRA- } \\
\text { BLOC TRADE }\end{array}$ & $\begin{array}{l}\text { RCA POST- } \\
\text { MERC }\end{array}$ & $\begin{array}{l}\text { VALUE OF EXTRA- } \\
\text { BLOC EXPORTS }\end{array}$ \\
\hline 687 & TIN & $-1049 \%$ & $105 \%$ & 2.77 & 49,932 \\
\hline 072 & COCOA & $.860 \%$ & $306 \%$ & 184 & 96,953 \\
\hline 058 & FRLAT PRESERVED, PREPARED & $.601 \%$ & $23 \%$ & 10.31 & $1,505,885$ \\
\hline 014 & MEAT PREPD, PRSVD, NES ETC & $-5.44 \%$ & $3.4 \%$ & 8.25 & 600,820 \\
\hline 532 & DYES NES, IANNING PROD & $.382 \%$ & $7.7 \%$ & 776 & 80,146 \\
\hline 268 & WOOL (EXC TOPSI, ANML HAIR & $-3.35 \%$ & $125 \%$ & 268 & 139,089 \\
\hline 672 & IRON, STEEL PRIMARY FORMS & $-258 \%$ & $15 \%$ & 519 & $1,583,294$ \\
\hline 673 & IRON, STEEL SHAPES ETC & $.228 \%$ & $17.9 \%$ & 1.06 & 305,724 \\
\hline 075 & SPICES & $.216 \%$ & $1.4 \%$ & 266 & 61,683 \\
\hline 612 & LEATHER ETC MANIFACTURES & $-207 \%$ & $15 \%$ & 208 & 146,696 \\
\hline 081 & FEEDNG STUFF FOR ANIMLS & $-158 \%$ & $1.4 \%$ & 1686 & $4,450,422$ \\
\hline 674 & IRN, STL UNIV, PLATE, SHEET & $129 \%$ & $11.5 \%$ & 147 & 882,878 \\
\hline 263 & COTION & $127 \%$ & $235 \%$ & 326 & 276,430 \\
\hline 658 & TEXTILE ARTICLES NES & $-125 \%$ & $27.8 \%$ & 105 & 167,563 \\
\hline 684 & ALUMINIUM & $124 \%$ & $3.9 \%$ & 287 & $1,435,885$ \\
\hline 762 & RADIO BROADCAST RECEIVRS & $-1.23 \%$ & $7.5 \%$ & 1.85 & 343,056 \\
\hline 713 & INTRNE COMBUS PSTN ENGIN & $-1.18 \%$ & $31.1 \%$ & 1.23 & 838,539 \\
\hline 851 & FOOTWEAR & $-100 \%$ & $77 \%$ & 3.48 & $1,404,729$ \\
\hline 062 & SUIGAR PREPS NON-CHOCLATE & $-0.82 \%$ & $33.4 \%$ & 1.74 & 82,729 \\
\hline 651 & TEXTILE YARN & $.070 \%$ & $220 \%$ & 122 & 479,211 \\
\hline 511 & HYDROCARBONS NES, DERIVS & $-057 \%$ & $6.6 \%$ & 1.19 & 259,006 \\
\hline 696 & CUTLERY & $-0.46 \%$ & $31.7 \%$ & 1.61 & 72,480 \\
\hline 848 & HEADGEAR, NONTXIL CLOTHNG & $.030 \%$ & $30 \%$ & 108 & 149,411 \\
\hline 625 & RUBBER TYRES, IUBES ETC & $-027 \%$ & $24.6 \%$ & 120 & 339,158 \\
\hline 512 & ALCOHOLS, PHENOLS ETC & $.0 .14 \%$ & $.33 \%$ & 132 & 204,858 \\
\hline 743 & PUMPS NES, CENTREUGES ETC & $-0.13 \%$ & $107 \%$ & 110 & 438,713 \\
\hline 071 & COFFE AND SUBSTITUIES & $.013 \%$ & $20 \%$ & 1500 & $2,499,625$ \\
\hline 662 & CIAY, REFRACIORY BIDG PRD & $.008 \%$ & $162 \%$ & 1.33 & 165,290 \\
\hline 041 & WHEAT ETC UNMILLED & $-0.05 \%$ & $34.9 \%$ & 2.43 & 490,674 \\
\hline
\end{tabular}

Source of the raw data: Comtrade - UNCTAD

A last point to notice is the performance of the top ten intra-bloc trade sectors over the whole period. In fact, when one observes the 10 main products in intra-bloc trade at SITC 03-digit level from 1987 to 1998 , the fears that Mercosur has not been in line with efficiency criteria are strengthening. Table 8 shows how significantly was the change in the major export sectors in intra-bloc trade from the preintegration to the post-integration period. More importantly, it shows a sharp increase in the number of products with a comparative disadvantage in intra-bloc trade in 1995-98 vis-à-vis the preintegration period. Even before the bloc formation the main intrabloc export products registered a lower competitive level in comparison to those products exported to third countries. However, this situation was aggravated significantly after the establishment of Mercosur. In 1987-90 there were only three products with an RCA 
below unity among the ten major exporting sectors, while in the postintegration period the number rose to eight with all the four major exporting products showing a comparative disadvantage, three of them belonging to the automotive regime. All those four products had a privileged access to the bloc own market through either an MFN import tariff much higher than the bloc average (in the case of the three first products belonging to the automotive sector) or were a target for managed trade (the case of crude petroleum (333)) ${ }^{16}$. The passenger motor vehicle (781) sector, which was the major exporting sector in 1995-98, showed a staggering RCA index of 0.18 in this period. Furthermore, the average RCA index for these 10 products declined from 1.88 in the pre-integration to 0.56 in the post-integration period. It means that the ratio of the RCA index of the 10 main export products to non-member countries in relation to bloc members soared from 3.5 to 16.0 from $1987-90$ to $1995-98$.

Table 8: Top Ten Products in Intra-Mercosur Trade

\begin{tabular}{|c|c|c|c|}
\hline CODE & SITC REV. 02 & $\begin{array}{c}\text { SHARE IN TOTAL } \\
\text { INTRA-BLOC IMPORTS }\end{array}$ & RCA INDEX \\
\hline \multicolumn{4}{|c|}{ A. PRE-MERC } \\
\hline 263 & COTION & $3.9 \%$ & 354 \\
\hline 611 & LEATHER & $39 \%$ & 637 \\
\hline 011 & MEAT RRESH, CHILLD, FROZEN & $39 \%$ & 3.17 \\
\hline 334 & PETROLEUM PRODUCTS, REHN & $35 \%$ & 1.18 \\
\hline 057 & RUIT, NUTS, RRESH, DRIED & $3.4 \%$ & 1.37 \\
\hline 784 & MOTOR VEH PRTS, ACCES NES & $34 \%$ & 0.56 \\
\hline 048 & CEREAL ETC PREPARATIONS & $3.2 \%$ & 0.16 \\
\hline 281 & IRON ORE, C NCENIRATES & $3.2 \%$ & 2289 \\
\hline 04$]$ & WHEAT ETC UNMILLED & $30 \%$ & 2.02 \\
\hline \multirow[t]{2}{*}{583} & POLYMERIZATION ETC PRODS & $29 \%$ & 0.80 \\
\hline & TOTAL & $34.2 \%$ & 1.88 \\
\hline \multicolumn{4}{|c|}{ B. POST-MERC } \\
\hline 781 & PASS MOTOR VEH EXC BUSES & $83 \%$ & 0.18 \\
\hline 784 & MOTOR VEH PRTS, ACCES NES & $5.4 \%$ & 0.76 \\
\hline 782 & IORRIES, SPCL MTR VEH NES & $51 \%$ & 0.62 \\
\hline 333 & CRUDE PETROLEUM & $45 \%$ & 0.55 \\
\hline 041 & WHEAT ETC UNMILLED & $32 \%$ & 2.43 \\
\hline 334 & PETROLEUM PRODUKTS, REFN & $2.7 \%$ & 0.47 \\
\hline 048 & CEREAL ETC PREPARATIONS & $26 \%$ & 0.19 \\
\hline 713 & NTRNL COMBUS PSTN ENGN & $25 \%$ & 123 \\
\hline 583 & POLYMERIZATION EIC PRODS & $22 \%$ & 0.40 \\
\hline \multirow[t]{2}{*}{641} & PAPER AND PAPERBOARD & $1.9 \%$ & 095 \\
\hline & TOTAL & $38.4 \%$ & 0.56 \\
\hline
\end{tabular}

Source of the raw data: Comtrade - UNCTAD.

${ }^{16}$ The MFN tariffs applied on imports of these 3 commodity groups from non-member countries was higher than $20 \%$ in Brazil and about 20\% in Argentina from 1995 to 1998. The MFN tariff for passenger motor vehicles (781) reached its peak of $70 \%$ in Brazil in 1995, declining since then to $35 \%$ in 1998 . No wonder that this sector became the top traded product within the bloc in the post-integration period. 
Table 9: Top Ten Products in Extra-Mercosur Exports

\begin{tabular}{|c|c|c|c|}
\hline CODE & SITC REV. 02 & $\begin{array}{c}\text { SHARE IN TOTAL } \\
\text { EXTRA-BLOC EXPORTS }\end{array}$ & RCA INDEX \\
\hline \multicolumn{4}{|c|}{ A. PRE-MERC } \\
\hline 081 & IEEDING STUFF FOR ANIMLS & $8.1 \%$ & 14.9 \\
\hline 281 & IRON ORE, CNCENTRATES & $4.9 \%$ & 22.9 \\
\hline 071 & COFEE AND SUBSTITUTES & $4.6 \%$ & 12.4 \\
\hline 222 & SEEDS FOR SOFT AXED OIL & $3.9 \%$ & 11.1 \\
\hline 058 & FRUIT PRESERVED, PREPARED & $3.3 \%$ & 12.6 \\
\hline 672 & IRON, STEEL PRIMARY FORMS & $3.2 \%$ & 60 \\
\hline 851 & FOOTWEAR & $3.0 \%$ & 3.5 \\
\hline 684. & ALUMINIUM & $3.0 \%$ & 3.2 \\
\hline 423 & FIXED VEG OILS, SOFT & $28 \%$ & 15.3 \\
\hline \multirow[t]{2}{*}{011} & MEAT RRESH, CHILLD, FROZEN & $28 \%$ & 32 \\
\hline & TOTAL & $39.5 \%$ & 7.7 \\
\hline \multicolumn{4}{|c|}{ B. POST-MERC } \\
\hline 081 & FEDING STUFF FOR ANIMLS & $7.5 \%$ & 16.9 \\
\hline 423 & FIXED VEG OLLS, SOFT & $4.8 \%$ & 21.4 \\
\hline 281 & RON ORE, C NCENTRATES & $4.5 \%$ & 26.5 \\
\hline 222 & SEEDS FOR SOFT FXED OIL & $4.4 \%$ & 16.1 \\
\hline 071 & COFEE AND SUBSTITUTES & $4.2 \%$ & 15.0 \\
\hline Oll & MEAT RRESH, CHILLD, FROZEN & $3.4 \%$ & 45 \\
\hline 061 & SUGAR AND HONEY & $3.3 \%$ & 127 \\
\hline 672 & IRON, STEEL PRIMARY FORMS & $2.7 \%$ & 5.2 \\
\hline 611 & IEATHER & $27 \%$ & 9.5 \\
\hline \multirow[t]{2}{*}{058} & FRUIT PRESERVED, PREPARED & $2.5 \%$ & 103 \\
\hline & TOTAL & $39.9 \%$ & 11.6 \\
\hline
\end{tabular}

Source of the raw data: Comtrade - UNCTAD.

In contrast to what occurred in intra-bloc trade, the main extrabloc export products showed a small degree of variability over the period examined (table 9). Although some of main export products to outside the bloc did not maintain their dynamism, as showed above, others did not replace them. Eight out of the ten main export products in the pre-integration period remained as such in the postintegration era, with only a few changes in their ranks. Feeding stuff for animals (081), for instance, remained as the major export product of the bloc over the period. This trend was observed in each of the main markets for Mercosur exports. The share of those products reached a maximum of about $60 \%$ in the EU and ASEAN+Japan, and a minimum of $34 \%$ in the Andean Pact in the post-integration period. All ten main export products of the bloc to the EU and ASEAN+Japan had comparative advantage in all three periods and the average RCA index for the 10 main export products rose in all blocs except NAFTA from 1987-90 to 1995-98. These products represented more than a third of total intra-bloc exports and about $40 \%$ of extra-bloc exports in all three periods. The results based on 
Mercosur major export sectors seem to confirm that, in contrast to what occurred with extra-regional exports, intra-Mercosur trade has not evolved according to the bloc comparative advantage. Moreover, it seems that the special treatment in intra-bloc trade, not granted in foreign markets, has played an important role in determining the opposite trends followed by exports to these two markets. This result is in accordance with Yeats (1997) analysis of Mercosur, although he reached his conclusions based on those products that showed the highest growth rates in regional orientation.

However, one may argue that the poor performance of Mercosur exports to outside the bloc during the period analysed could be provoked by higher trade barriers faced by the bloc exports on third markets rather than lack of competitiveness. Recent research has shown that some of the export products of developing and least developed countries face high barriers to entry into developed countries, in the form of tariff peaks, NTBs and subsidies on domestic production (e.g. Hoekman et al., 2001; and OECD, 2001a). For instance, tariff peaks tend to be concentrated in agriculture, food products and in labour intensive sectors such as footwear and apparel, products typically exported by developing countries. The Brazilian government has also stressed the high level of protection faced by some of its major export products in developed countries, especially in the EU and in the United States (Brazilian Embassy; 2000a and 2000b; and Fonseca et al., 1999). Brazil's exports of sugar and tobacco, for instance, face tariffs as high as $236 \%$ and $350 \%$, respectively, in the USA (Brazilian Embassy, 2000a).

Nevertheless, there is no compelling evidence that trade barriers increased from 1987 to 1998 either for developing countries in general or for Mercosur members in particular. Indeed, despite the process of tariffication (replacing quantitative restrictions and other NTBs with tariffs) as a result of the Uruguay Round (completed in 1994), there was no sign that tariffs increased compared to 1986. Finger et al. (1996) estimate that the applied weighted average tariff in USA and the EU, the major export markets for Mercosur, would decline in both agricultural and industrial products, as part of the Uruguay Round ${ }^{17}$. Besides, tariffs applied on agricultural products were

${ }^{17}$ The post-Uruguay Round applied tariff for agricultural products would fall by $2.6 \%$ and $4.4 \%$ in USA and the EU until 1999, respectively, with a gradual implementation taking place between 
required to decline by $36 \%$ on average from 1995 to 2000 for industrial countries. Furthermore, the high tariffs faced by some Mercosur export products should not be blamed for the poor performance of Mercosur exports to the rest of the world since high tariffs still allow export growth; it is only rising tariffs that do not. Stringent quantitative restrictions and subsidies granted by developed countries to domestic production would effectively prevent export growth for products from developing countries. However, as far as of support for agriculture granted by industrial countries is concerned, it seems that although it remains high there was not a rise in overall support during the 1990s. For the OECD as a whole, total support for agriculture, as measured by Total Support Estimate (TSE) ${ }^{18}$, decreased form $2.2 \%$ of GDP in the period 1986-88 to $1.3 \%$ in 2000 (OECD, 2001b). Moreover there was a reduction in both import barriers and export subsidies in the same period, with the prices received by farmers $43 \%$ above those in world markets in 2000, compared to $61 \%$ in $1986-88$ (OECD, $2001 \mathrm{~b})^{19}$. With regard to the contingent measures, only five Mercosur export products were subject to initiation of $\mathrm{AD}$ investigations by nonmember countries in the period 1997-98, while only one product was subject to initiation of a CVD investigation in the same period. Finally, it is worth noting that the import growth of both the EU and NAFTA exceeded that observed by Mercosur extra-bloc exports (49.9\%) from $1987-90$ to $1994-98$, reaching $111.1 \%$ in NAFTA and $70.4 \%$ in the EU, indicating that the bloc has not followed the export dynamism of other regions.

Table 10 summarises the main points stressed in this section emphasising the number of sectors and the value of both trade diversion and 'export diversion' according to the methods employed. It can be seen that whatever the method used, the signs of export diversion exceed those of trade diversion in both number of sectors affected and the value involved. With regards to the number of

1995 and 1998 (Finger et al., 1996). It is worth noting that as some of the tariffs that emerged from the Uruguay Round are specific rates or combination tariffs, with both ad valorem and specific components, they were not computed in the tariff average leading to an underestimation of the actual tariff rates.

18 TSE is an indicator of the annual monetary value of all gross transfers from taxpayers and consumers arising from policy measures that support agriculture, net of associated budgetary receipts. ${ }^{19}$ The overall reduction in market protection for agricultural products in the OECD area may partially reflect the process of achieving WTO commitments (OECD, 2001b). 
sectors, approximately three times more are likely to be involved in export diversion than trade creation in both methods. Meanwhile, the absolute value estimated of 'export diversion' surpasses by approximately $50 \%$ that related to trade diversion when the absolute changes are considered. This difference, however, surges up when the changes in shares are taken into account with the value of 'export diversion' exceeding that related to trade diversion by approximately 13 times. This reflects the fact that, although Mercosur has not been immune to trade diversion in some areas, its most likely effect is related to 'export diversion'.

Table 10: Summary of Trade Diversion and Export Diversion (Value in US\$ million)

\begin{tabular}{ccccc}
\hline Method & \multicolumn{2}{c}{ Trade Diversion } & \multicolumn{2}{c}{ Export Diversion } \\
\hline & No Sectors & Value & No Sectors & Value \\
Absolute Changes & 21 & $-2,135$ & 61 & $-3,054$ \\
Share Changes & 33 & $-1,110$ & 89 & $-13,942$ \\
\hline
\end{tabular}

Source of raw data: Comtrade - UNCTAD

\section{Conclusion}

As stressed above, the methodology employed in this paper to assess the impact of Mercosur on trade patterns, based on descriptive statistics, is only a first step towards a more rigorous analysis. Its major drawback refers to its inability to separate out the impact of the bloc from the other variables influencing the pattern of trade, attributing "too much" to the bloc effect. However, it provided preliminary insights concerning the effects of Mercosur. The foregoing analysis showed that intra-Mercosur total trade performance has exhibited a completely different pattern from extra-bloc exports. Total intra-bloc trade surged up approximately five times from the preintegration period to $1995-98$ and imports from non-member countries went up significantly as well, while total extra-bloc exports increased by a mere $50 \%$. The analysis based on the intensity of trade index confirms those signals, with the intra-bloc intensity index going up significantly over the period observed, although it was already high even before Mercosur formation, meaning that trade within the region was already geographically biased. Meanwhile, the propensity 
to import from non-member countries did not decline, but on the contrary, rose for all blocs analysed, although the propensity to export extra-regionally fell for all blocs but the EU.

Despite the lack of signs of trade diversion at bloc level when total imports are concerned, since imports from outside the bloc increased sharply, when the analysis is performed at the SITC 03digit level the situation is not so comforting. About $14 \%$ of sectors at that level of aggregation showed a significant rise in intra-bloc trade without having comparative advantage, measured by both the revealed comparative advantage index and by their performance in third markets. However, the signs of 'export diversion' were much more vivid than the traditional trade diversion, comprising approximately a third of the value exported to the rest of the world in the post-integration period. Analysis of Mercosur major export products to both members and non-member countries also showed that regional integration seems to have played an important role in the different evolution of intra-bloc and extra-bloc exports. While most products exported to non-member countries remained the same and showed significant revealed comparative advantages in all three periods examined, there were substantial changes in the products exported within the bloc, with none of the top four export products showing revealed comparative advantage in the post-integration period. All these four products had in common a privileged access to the bloc own market either through MFN import tariffs much higher than the bloc average or as a target for managed trade.

This scenario has changed dramatically in the last years following the Brazilian currency devaluation in January 1999 and Argentina's default crisis in 2001. Mercosur's intra-bloc trade has shrunk since then reaching levels quite bellow its peak in 1997. Brazilian exports to Argentina in 2002, for instance, declined to about a third of the value of 1997 (from US $\$ 9,046$ million to US $\$ 3,310$ million). The crisis faced by the bloc in the last years led some to predict a dark future for Mercosur. However, late developments has changed the picture, like the strong commitment of the new Presidents of Argentina and Brazil to revive the integration process along with the recovery of Argentinean economy from the collapse observed in 2001-02 and the realignment of bloc's main partners exchange rates. Nevertheless, in order to achieve the level of intra-bloc trade observed in the late 1990 s once again it would be necessary much more than words. 
Only sound macroeconomic policies and a real commitment to eliminate all the remaining barriers that still affect intra-bloc trade could provide it.

\section{References}

Anderson, K. and H. Norheim (1993), 'History, geography and regional integration', in K Anderson and R. Blackhurst (eds.), Regional Integration and the Global Trading System. London: Harvester-Wheatsheaf, 19-51.

Balassa, B. (1965), 'Trade liberalization and revealed comparative advantage', The Manchester School of Economic and Social Studies, 23, 99-124.

Brazilian Embassy (2000a), 'Barreiras aos Produtos e Serviços Brasileiros no Mercado Norte-Americano, Washington, DC.

Brazilian Embassy (2000b), 'Obstáculos ao Acesso das Exportações do Brasil ao Mercado Comunitário', Washington, DC.

Devlin, R. (1997), 'In Defence of Mercosur', Revista Brasileira de Comércio Exterior, 12 (January-March), Brazil.

Eichengreen, B. and D. Irwin (1997), 'The role of history in bilateral trade flows', in J. Frankel (ed.), Regionalization of the World Economy, Chicago: University of Chicago Press, 33-57.

Finger, J., M. Ingco and U. Reincke (1996), The Uruguay Round: Statistics on Tariff Concessions Given and Received', Washington DC: World Bank.

Fonseca, C., M. Carvalho Jr., G. Ferraz Filho, H. Pourchet, R. Markwald and F. Silva (1999), 'Barreiras externas às exportações brasileiras', Funcex Working Paper, $\mathrm{n}^{\circ}$ 146, Rio de Janeiro.

Frankel, J. (1997), Regional Trading Blocs in the World Economic System, Washington DC: Institute for International Economics.

Hoekman, B., F. Ng and M. Olarreaga (2001), 'Eliminating excessive tariffs on exports of least Developed Countries', World Bank Working Papers, $\mathrm{n}^{\circ} 2604$, Washington DC, available at: http://econ.worldbank.org/files/2196 wps2604.pdf.

Krueger, A. (1999), 'Trade creation and trade diversion under NAFTA', NBER Working Paper, $n^{\circ} 7429$, National Bureau of Economic Research, available at: http://www.nber.org/papers/w7429.

Nagarajan, N. (1998), 'Mercosur and trade diversion: What do the imports figures tell us?', Economic Papers, Working Papers Series, European Commission, ${ }^{\circ}$ 129, Brussels. 
OECD - Organisation for Economic Co-operation and Development (2001a), 'Agricultural Policies in Emerging and Transition Economies: Special Focus on Non-Tariff Measures', Paris: OECD, available at: http://www1.oecd.org/ publications/e-book/1401121e.pdf.

OECD - Organisation for Economic Co-operation and Development (2001b), 'Agricultural Policies in OECD Countries: Monitoring and Evaluation', Paris:

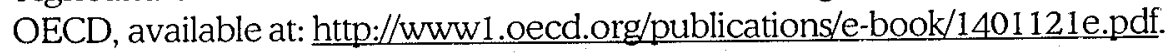

Perkins, D. and M. Syrquin (1989), 'Large countries: The influence of size', in H. Chenery and T. Srinivasan (eds.), Handbook of Development Economics, vol. 2, Amsterdam: North-Holland.

Primo Braga, C., R. Safadi and A. Yeats (1994), 'Regional integration in the Americas: Deja vu all over again?', World Economy, 17, 577-601.

Soloaga, I. and L. A. Winters (2001), 'Regionalism in the nineties: What effect on trade?', The North American Journal of Economics and Finance, 12, 1-29.

Viner, J. (1950), The Custom Union Issue, London: Carnegie Endowment for International Peace.

Winters, L. A. (1997), 'Regionalism and the rest of the world: The irrelevance of the Kemp-Wan theorem', Oxford Economic Paper, 49, 228-234.

Yeats, A. (1997), 'Does Mercosur's trade performance raise concerns about the effects of Regional Trade Arrangements', Policy Research Work Paper, n 1729, Washington DC: World Bank. 